\title{
Pemanfaatan Serbuk Gergaji Kayu Jati dan Sengon sebagai Bahan Dasar Penghasil Gula Reduksi
}

\author{
Kristina Tresia Leto \\ IKIP Muhammadiyah Maumere, Maumere, Indonesia \\ kristinatresia922@gmail.com \\ ${ }^{*}$ Corresponding author
}

Kata Kunci:

Serbuk Gergaji Kayu;

Delignifikasi; Hidrolisis, Gula

Reduksi

\begin{abstract}
ABSTRAK
Telah dilakukan penelitian pembuatan gula reduksi dengan memanfaatkan serbuk gergaji dari kayu Jati dan kayu Sengon. Gula reduksi yang dihasilkan digunakan sebagai reduktor pada pengolahan bijih Mangan. Penambahan reduktor bertujuan untuk mengubah Mn (IV) yang tidak larut dalam asam menjadi Mn (II) yang larut dalam asam. Proses penelitian dilakukan melalui 4 tahapan, yaitu penghilangan air, delignifikasi, hidrolisis selulosa dan penentuan kadar gula reduksi hasil hidrolisis. Serbuk gergaji kayu Jati memiliki kadar air sebesar 1,65\% sedangkan kayu Sengon 1,75\%. Selanjutnya, dilakukan proses delignifikasi dengan $\mathrm{NaOH} \mathrm{0,1}$ $M$ selama 2 jam dengan suhu $55^{\circ} \mathrm{C}$, diperoleh kadar selulosa serbuk gergaji kayu Jati sebesar 77,6\% sedangkan kayu Sengon 83,0\%. Proses hidrolisis menggunakan $\mathrm{H}_{2} \mathrm{SO}_{4} \quad 12 \%$ pada suhu $110^{\circ} \mathrm{C}$ selama 1 jam dan diperoleh kadar gula reduksi untuk serbuk gergaji kayu Jati sebesar 49,36\% sedangkan kayu Sengon sebesar 38,52\%.
\end{abstract}

\section{PENDAHULUAN}

Kayu Jati dan kayu Sengon merupakan jenis kayu yang banyak tersebar di sebagian besar wilayah Indonesia. Kedua jenis kayu ini merupakan tanaman yang cepat tumbuh dan bahkan banyak dibudidayakan oleh masyarakat karena memiliki nilai jual yang cukup tinggi. Kayu Jati dan Sengon banyak digunakan sebagai bahan pembangunan rumah (konstruksi), sebagai bahan dasar kursi, meja, ataupun lemari. Penggunaan dua jenis kayu yang cukup tinggi tersebut berdampak pada penumpukan limbah kayu, salah satunya adalah serbuk gergaji. Serbuk gergaji adalah limbah yang dihasilkan dari proses menggergaji kayu. Serbuk gergaji sering ditemukan hampir di setiap tempat pengolahan kayu ataupun di sektor pertanian. Sejauh ini, serbuk gergaji hanya dimanfaatkan sebagai media tanam jamur putih, pembuatan briket dan papan partikel (Trisanti dkk., 2018). Selain itu, serbuk gergaji lebih sering dibuang, ditumpuk lalu dibiarkan membusuk atau dibakar sehingga sangat berdampak negatif terhadap lingkungan.

Sejauh ini, pemanfaatan serbuk gergaji masih sangat terbatas. Salah satu alternatif pemanfaatan serbuk gergaji sehingga dapat bernilai jual tinggi adalah menjadikannya sebagai reduktor. Dalam bidang kimia, serbuk gergaji dapat digunakan sebagai reduktor karena mengandung selulosa. Selulosa $\left(\mathrm{C}_{6} \mathrm{H}_{10} \mathrm{O}_{5}\right)$ n terdiri dari rantai panjang polimer yang terbentuk dari monomer glukosa. Produk turunan dari selulosa berupa glukosa (gula reduksi) yang dihasilkan dari proses hidrolisis dapat dijadikan 
sebagai reduktor. Berdasarkan penelitian yang sudah dilakukan oleh Hariprasad dkk. (2007), serbuk gergaji dapat digunakan sebagai bahan reduktor pada pelindihan bijih Mangan.

Serbuk gergaji kayu digolongkan sebagai reduktor organik. Penggunaan reduktor organik telah banyak digunakan dalam proses pelindihan Mangan seperti molases (Lasheen, El Hazek, \& Helal, 2009), cornstalk (Cheng, Zhu, \& Zhao, 2009), limbah teh (Tang dkk., 2014), corncob (Tian dkk., 2010) dan limbah tandan sawit (Wahyudi, Zaharah, \& Wahyuni, 2013). Reduktor organik dipilih karena sifatnya yang ramah lingkungan dan rendah biaya. Selain itu, reduktor organik memiliki gugus fungsi yang mudah teroksidasi seperti monomer karbohidrat yang memiliki gugus aldehida dan keton.

Proses ekstraksi selulosa dilakukan melalui proses delignifikasi dengan alkali. Proses ini bertujuan untuk menghilangkan lignin yang terikat pada selulosa. Tahap selanjutnya adalah hidrolisis untuk mendapatkan monomer glukosa. Proses hidrolisis dilakukan dalam suasana asam yakni dengan asam sulfat. Tahap yang terakhir adalah mengetahui keberadaan gula reduksi menggunakan pereaksi benedict dan menentukan kadar gula reduksi dengan metode Luff Schoorl. Tujuan dari penelitian ini adalah untuk mengetahui kadar gula reduksi dari kayu Jati dan kayu Sengon yang dapat dijadikan sebagai bahan reduktor pada pelindihan bijih Mangan.

\section{METODE PENELITIAN}

\section{Preparasi Serbuk Gergaji Kayu dan Penentuan Kadar Air}

Serbuk gergaji kayu Jati dan kayu Sengon terlebih dahulu dikeringkan dengan proses dibiarkan pada suhu ruang. Selanjutnya, serbuk gergaji kayu yang masih kasar dihaluskan dengan blender dan diayak hingga lolos ayakan $250 \mu \mathrm{m}$. Serbuk gergaji kayu yang lolos ayakan dipanaskan dalam oven dengan suhu $40^{\circ} \mathrm{C}$ selama 6 jam untuk menghilangkan kandungan air. Hasil dari pemanasan tersebut didinginkan dalam desikator selama 10 menit dan ditimbang untuk mendapatkan berat konstan.

\section{Delignifikasi Serbuk Gergaji Kayu dengan Alkali}

Sebanyak 20 g serbuk halus gergaji kayu didelignifikasi dengan $400 \mathrm{~mL}$ larutan $\mathrm{NaOH} 0,1 \mathrm{M}$. Campuran tersebut diaduk dengan kecepatan pengadukan $600 \mathrm{rpm}$ dan suhu $55^{\circ} \mathrm{C}$ selama 2 jam. Filtratnya dianalisis secara kualitatif dengan ditetesi larutan phloroglucinol dalam asam klorida untuk mengetahui adanya lignin. Residu dicuci dengan aqua demineral hingga $\mathrm{pH} 7$ dan dikeringkan dalam oven pada suhu $105^{\circ} \mathrm{C}$ kemudian ditimbang untuk mendapatkan berat konstan.

\section{Hidrolisis Serbuk Gergaji Kayu}

Sebanyak 15 g serbuk halus gergaji kayu dihidrolisis dengan $150 \mathrm{~mL} \mathrm{H}_{2} \mathrm{SO}_{4} 12 \%$ selama 1 jam dengan suhu $110^{\circ} \mathrm{C}$ dan kecepatan pengadukan $700 \mathrm{rpm}$. Filtrat kemudian dinetralkan dengan $\mathrm{NaOH}$ 0,5 M dan disaring. Selanjutnya, dilakukan uji kualitatif untuk mengetahui adanya gula reduksi dengan pereaksi Benedict sedangkan secara kuantitatif dengan metode Luff Schrool.

\section{HASIL DAN PEMBAHASAN}

\section{Preparasi Serbuk Gergaji Kayu}

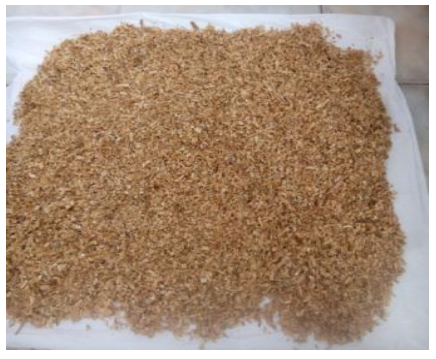

(a)

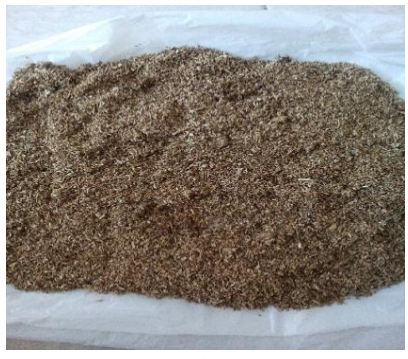

(b)

Gambar 1. Serbuk Gergaji: (a) Kayu Jati, (b) Kayu Sengon 
Serbuk gergaji kayu perlu dipreparasi terlebih dahulu untuk mendapatkan glukosa yang maksimal. Proses preparasi dilakukan melalui tahap pengecilan ukuran, pengayakan dan pengeringan untuk menghilangkan kadar air. Proses pengecilan ukuran dilakukan menggunakan blender lalu diayak dengan ukuran ayakan $250 \mu \mathrm{m}$. Selanjutnya, serbuk yang telah lolos ayakan di oven selama 4 jam dengan suhu $60^{\circ} \mathrm{C}$ untuk menghilangkan kandungan air dan mencegah agar serbuk tidak mengalami kerusakan dalam waktu yang lama akibat reaksi kimia dan aktivitas mikroba. Persentase kadar air serbuk gergaji kayu Jati dan Sengon disajikan pada Gambar 2.

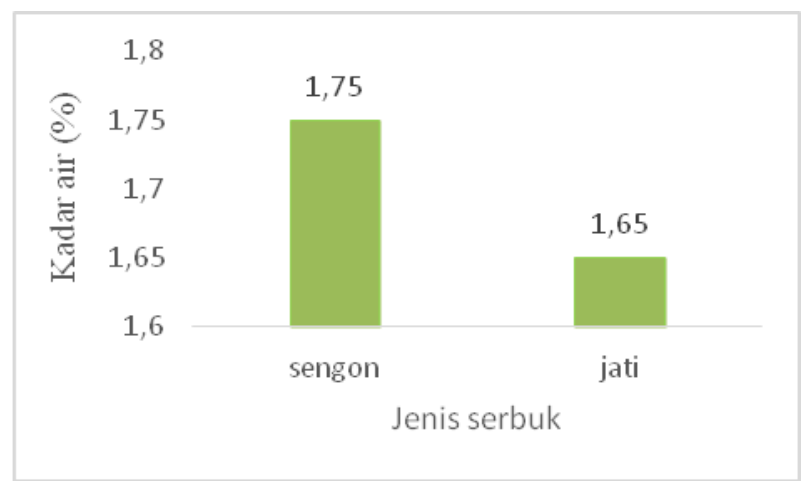

Gambar 2. Persentase Perolehan Kadar Air

Serbuk gergaji kayu Sengon memiliki kandungan air yang lebih tinggi dibandingkan kayu Jati karena kayu Sengon memiliki serat yang cukup tinggi. Semakin tinggi serat maka kandungan air semakin banyak (Hartati dkk., 2011). Kayu Sengon juga merupakan jenis kayu lunak yang memiliki kandungan selulosa yang lebih tinggi dibandingkan kayu keras (Effendi, Gerhauser, \& Bridgwater, 2008). Kandungan selulosa yang tinggi menyebabkan kayu lunak memiliki gugus $\mathrm{OH}^{-}$yang lebih banyak sehingga memiliki kemampuan yang lebih tinggi dalam mengikat air.

\section{Delignifikasi Serbuk Gergaji Kayu dengan Alkali}

Serbuk gergaji kayu mengandung senyawa lignin yang berperan sebagai pelindung selulosa. Adanya senyawa tersebut menyebabkan serbuk gergaji kayu bersifat keras dan kuat sehingga perlu dilakukan proses delignifikasi. Jika lignin tidak dihilangkan terlebih dahulu maka struktur lignin akan menghambat selulosa sehingga sulit untuk dihidrolisis menjadi glukosa. Proses delignifikasi dilakukan secara kimia menggunakan larutan alkali yang dapat menyerang dan merusak struktur lignin dan dapat mengembangkan struktur selulosa. Penggunaan alkali juga memiliki keuntungan, diantaranya dapat meningkatkan luas permukaan, menurunkan derajat polimerisasi, dan kristalinitas. Tidak hanya lignin yang terdegradasi dalam alkali tetapi juga hemiselulosa karena derajat polimerisasinya yang lebih rendah dari selulosa (Sun \& Cheng, 2002).

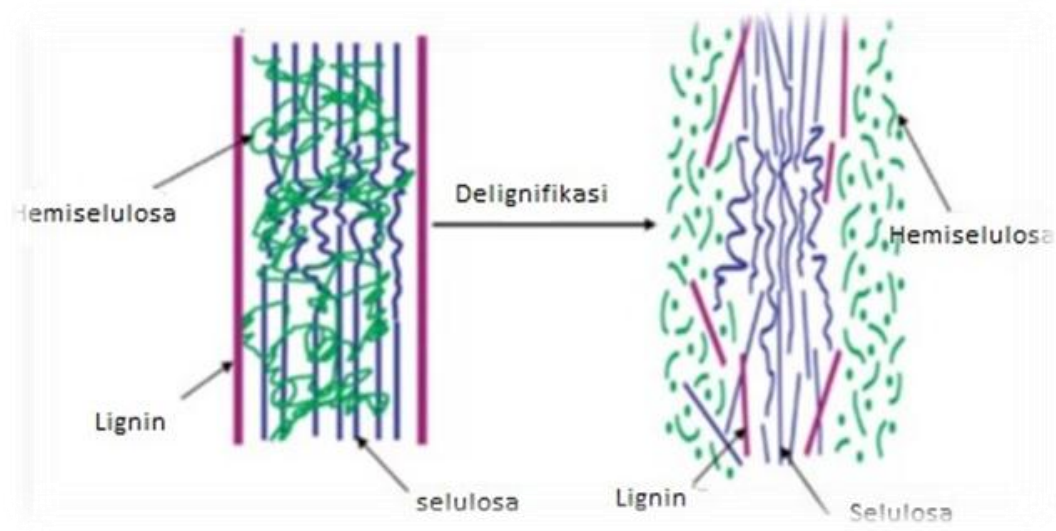

Gambar 3. Skema Proses Delignifikasi (Astner, 2012) 
Keberadaan lignin secara kualitatif dalam suatu jaringan tumbuhan dapat diketahui dengan metode histokimia menggunakan pewarnaan Phloroglucinol-HCl. Serbuk hasil delignifikasi ditetesi dengan larutan Phloroglucinol-HCl dan jika terbentuk warna merah maka serbuk tersebut masih mengandung lignin (Hartati dkk., 2011).

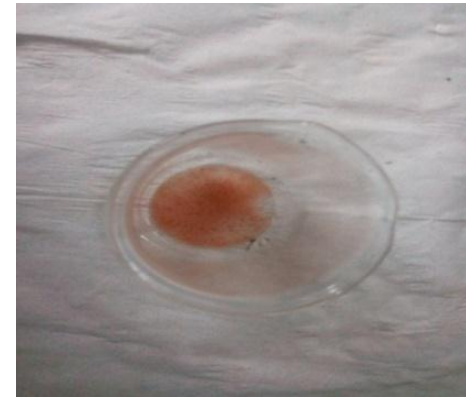

(a)

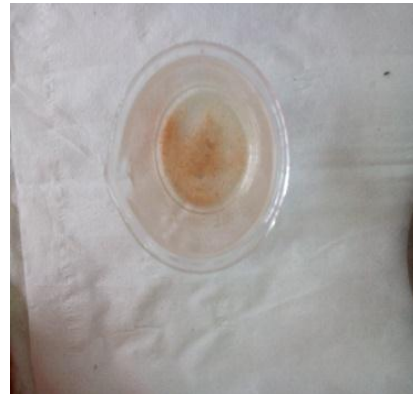

(b)

Gambar 4.Uji Lignin pada Serbuk Gergaji: (a) Kayu Sengon dan (b) Jati

Pada proses delignifikasi, ion $\mathrm{OH}^{-}$dari $\mathrm{NaOH}$ akan memutuskan ikatan dari struktur dasar lignin sedangkan ion $\mathrm{Na}^{+}$berikatan dengan lignin membentuk natrium fenolat yang mudah larut dalam air. Reaksi delignifikasi serbuk gergaji kayu dengan $\mathrm{NaOH}$ dapat dilihat pada Gambar 5.

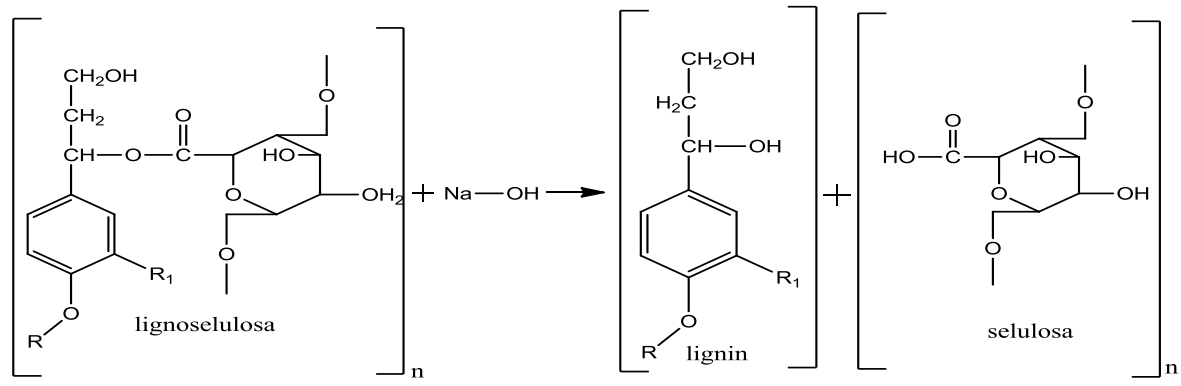

Gambar 5. Reaksi Delignifikasi Serbuk Gergaji Kayu dengan $\mathrm{NaOH}$

Adapun persentase perolehan selulosa hasil delignifikasi disajikan pada Gambar 6.

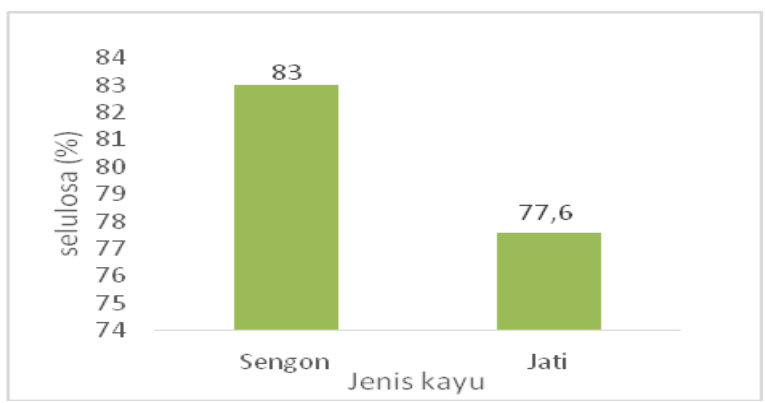

Gambar 6. Persentase Selulosa

\section{Hidrolisis Serbuk Gergaji Kayu}

Proses hidrolisis bertujuan untuk memecah molekul polisakarida menjadi monomer gula penyusunnya. Hidrolisis dilakukan pada suhu $110^{\circ} \mathrm{C}$. Semakin tinggi suhu dapat menyebabkan terjadinya reaksi lebih lanjut yang membentuk senyawa lain, seperti asam karboksilat, senyawa furan, dan senyawa fenol. Berikut reaksi hidrolisis serbuk gergaji kayu dengan asam sebagai katalis (Sun \& Cheng, 2002).

$$
\underset{\text { selulosa }}{\left(\mathrm{C}_{6} \mathrm{H}_{10} \mathrm{O}_{5}\right)_{n}}+{ }_{n} \mathrm{H}_{2} \mathrm{O} \stackrel{\text { katalis asam }}{\longrightarrow} \underset{{ }_{n} \mathrm{C}_{6} \mathrm{H}_{12} \mathrm{O}_{6}}{\text { glukosa }}
$$


Proses hidrolisis dilakukan dalam suasana asam dengan pemecahan ikatan glikosida yang berlangsung dalam 3 tahap. Tahap pertama, proton yang bersikap sebagai katalis asam akan berinteraksi cepat dengan oksigen glikosida yang menghubungkan 2 unit gula (I) lalu membentuk asam konjugat (II). Pada proses ini diikuti dengan pemecahan yang lambat dari ikatan $\mathrm{C}-\mathrm{O}$ dan menghasilkan zat antara berupa kation karbonium siklik (III). Selanjutnya, kation karbonium mengasidasi molekul air dengan cepat dan membentuk glukosa yang stabil dan melepaskan proton (Putri \& Supartono, 2015).

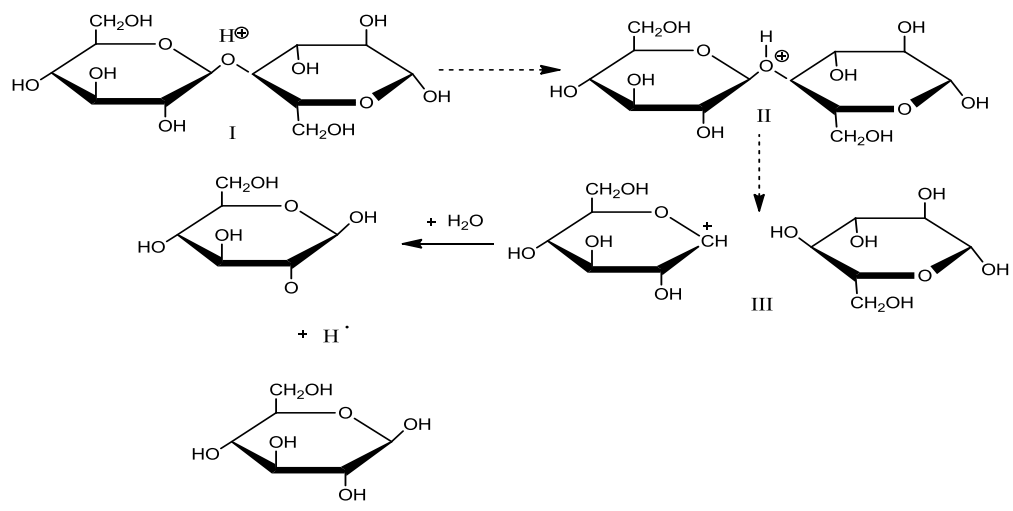

Gambar 7. Mekanisme Reaksi Hidrolisis

Adapun beberapa senyawa inhibitor yang dapat terbentuk selama proses hidrolisis menggunakan asam encer, antara lain: furfural, hydroxymethylfurfural (HMF), asam levulinik, (levulinic acid), asam asetat (acetic acid), asam format (formic acid), asam uronat (uronic acid), asam 4-hydroxybenzoic, asam vanilik (vanilic acid), vanillin, phenol, cinnamaldehyde, formaldehida (formaldehyde), dan beberapa senyawa lain (Osvaldo, Putra, \& Faizal, 2012).

Proses hidrolisis pada penelitian ini menghasilkan filtrat berwarna bening yang diperkirakan mengandung monomer-monomer gula akibat ikatan glikosida yang mudah dipecahkan oleh asam. Filtrat dinetralkan dengan $\mathrm{NaOH}$ hingga mencapai $\mathrm{pH}$ 7. $\mathrm{pH}$ filtrat tidak boleh mencapai $\mathrm{pH}$ basa karena dapat merusak struktur cincin pada karbohidrat.

\section{Penentuan Gula Reduksi Hasil Hidrolisis}

Secara kualitatif, uji gula reduksi hasil hidrolisis serbuk gergaji kayu dilakukan menggunakan pereaksi Benedict. Adanya gula reduksi dalam filtrat diketahui dengan terbentuknya warna merah bata. Reaksi yang terjadi pada proses ini yakni glukosa mereduksi ion $\mathrm{Cu}^{2+}$ dari kuprisulfat membentuk ion $\mathrm{Cu}^{+}$dan kemudian mengendap sebagai $\mathrm{Cu}_{2} \mathrm{O}$.

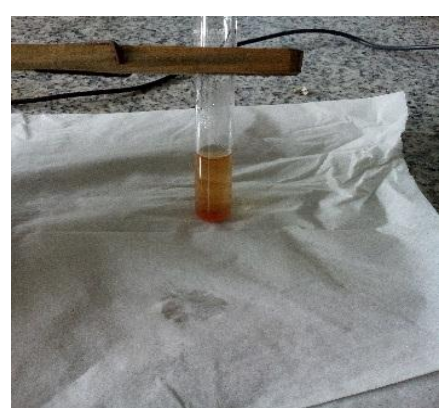

(a)

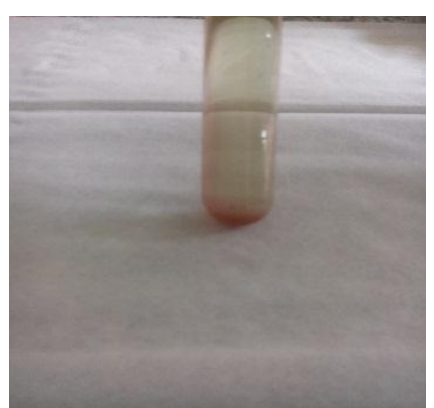

(b)

Gambar 8. Uji Kualitatif Gula Reduksi pada Serbuk Gergaji: (a) Kayu Jati dan (b) Sengon

Uji gula reduksi secara kuantitatif dilakukan dengan metode Luff Schrool. Prinsip dasar metode Luff Schrool adalah menentukan mg glukosa berdasarkan tabel penetapan gula Luff Schrool dengan selisih volume titran (natrium tiosulfat). Reaksi yang terjadi pada penentuan gula reduksi dengan Luff Schrool, mula-mula glukosa yang dihasilkan adalah monosakarida hasil hidrolisis mereduksi $\mathrm{CuO}$ 
dalam larutan Luff menjadi $\mathrm{Cu}_{2} \mathrm{O}$. Kelebihan $\mathrm{CuO}$ akan direduksi dengan $\mathrm{KI}$ berlebih sehingga membebaskan $\mathrm{I}_{2}$. Selanjutnya, $\mathrm{I}_{2}$ yang bebas tersebut dititrasi dengan larutan Na-Tiosulfat. Berdasarkan hasil perhitungan diperoleh kadar gula reduksi untuk serbuk gergaji kayu Jati lebih besar dibandingkan serbuk gergaji kayu Sengon.

Tabel 1. Persentase Gula Reduksi

\begin{tabular}{cccc}
\hline No & Jenis serbuk & Serbuk terhidrolisis (g) & Gula reduksi (\%) \\
\hline 1 & Jati (Tectona grandis L.f) & 3,04 & 49,36 \\
2 & Sengon (Albizia chinensis) & 3,26 & 38,52 \\
\hline
\end{tabular}

\section{KESIMPULAN}

Berdasarkan penelitian yang telah dilakukan maka dapat disimpulkan bahwa serbuk gergaji kayu jati memiliki kandungan gula reduksi yang lebih tinggi dibandingkan dengan serbuk gergaji kayu sengon yakni $49,36 \%$ dan $38,52 \%$.

\section{DAFTAR PUSTAKA}

Astner, A. F. (2012). Lignin Yield Maximization of Lignocellulosic Biomass by Taguchi Robust Product Design using Organosolv Fractionation. Tesis. University of Tennessee, Knoxville.

Cheng, Z., Zhu, G., \& Zhao, Y. (2009). Study in Reduction-Roast Leaching Manganese From LowGrade Manganese Dioxide Ores Using Cornstalk as Reductant. Hydrometallurgy, 176-179.

Effendi, A., Gerhauser, H., \& Bridgwater, A. V. (2008). Production of Renewable Phenolic Resins By Thermochemical Conversion of Biomass: A review. Renewable and Sustainable Energy Reviews, 12, 2092-2116.

Hariprasad, D., Dash, B., Ghosh, M. K., \& Anand, S. (2007). Leaching Of Manganese Ores Using Sawdust as a Reductant. Minerals Engineering, 20, 1293-1295.

Hartati, N. S., Sudarmonowati, E., Suharsono, \& Sofyan, K. (2011). Quantitative Analysis And Lignin Histochemical Assay of Sengon (Paraserianthes falcataria). Widyariset, 14(3).

Lasheen, T., El Hazek, M. N., \& Helal, A. S. (2009). Kinetics of Reductive Leaching of Manganese Oxide Ore With Molasses in Nitric Acid Solution. Hydrometallurgy, 98, 314-317.

Osvaldo, Z. S., Putra S., \& Faizal, M. (2012). Pengaruh Konsentrasi Asam dan Waktu Pada Proses Hidrolisis dan Fermentasi Pembuatan Bioetanol Dari Alang-alang. Jurnal Teknik Kimia, $18(2)$.

Putri, E. S., \& Supartono. (2015). Pemanfaatan Limbah Tandan Kelapa Untuk Pembuatan Bioetanol Melalui Proses Hidrolisis Dan Fermentasi. Indonesian Journal of Chemical sciense, 4(2).

Sun, Y., \& Cheng, J. (2002). Hydrolysis of Lignocellulosic Materials For Ethanol Production: A Review. Bioresource Technology, 83, 1-11.

Tang, Q., Zhong, H., Wang, S., Li, J. Z., \& Liu, G. Y. (2014). Reductive Leaching of Manganese Oxide Ores Using Waste Tea as Reductant inSsulfuric Acid Solution. Transactions of Nonferrous Metals Society of China, 24, 861-867.

Tian, X., Wen, X., Yang, C., Liang, Y., Pi, Z., \& Wang, Y. (2010). Reductive Leaching of Manganese From Low-Grade Manganese Dioxide Ores Using Corncob as Reductant in Sulfuric Acid Solution. Hydrometallurgy, 100, 157-160.

Trisanti, P. N., Putra, S. S, H., Nura'ini, E., \& Sumarno. (2018). Ekstraksi Selulosa Dari serbuk Gergaji Kayu Sengon Melalui Proses Delignifikasi Alkali Ultrasonik. Jurnal Sains Materi Indonesia, 19(3), 113-119.

Wahyudi, H., Zaharah, T. A., \& Wahyuni, N. (2013). Ekstraksi Mangan Dengan Proses Leaching Asam Sulfat Menggunakan Tandan Kosong Sawit Sebagai Reduktor. Jurnal Kimia Khatulistiwa, 2(1), 34-37. 